\title{
Breaking Laws to Fix Broken Windows: A Revisionist Take on Order Maintenance Policing
}

\author{
Andrew Ingram*
}

Today, there is a family of celebrated police strategies that teach the importance of cracking down on petty crime and urban nuisance as the key to effective crime control. Under the "broken windows" appellation, this strategy is linked in the public mind with New York City and the alleged successes of its police department in reducing the rate of crime over the past two decades. This paper is critical of such order maintenance approaches to policing: I argue that infringements of civil liberty by such departments could be reduced if the departments looked at law more as a good to be served for its own sake and less as an instrument for the promotion of order. In other words, a shot of legalism is the correct medicine to reduce police misconduct that pierces the law's protections of citizen freedom.

This Article contributes to the critical literature on broken windows policing by reassessing the work of the famous Harvard scholar (James Q. Wilson) who fathered it. The Article takes Wilson's work and turns it on its head, drawing very different prescriptive conclusions than he did himself.

I. Background

A. Distinguishing Law and Order as Objectives of the Police .. 114

B. James Q. Wilson: Police Styles and Broken Windows 116

1. The Concept of Police Style 116

2. The Watchman and Legalistic Styles 119

3. From the Watchman Style to Broken Windows 124

* A.B., Brown University, 2009; M.A., The University of Texas at Austin, 2013; J.D.,The University of Texas School of Law, 2013. I would like to thank Professor Jennifer Laurin for her encouragement and the excellent seminar that produced this Article. I am grateful as well for the editing and criticism I received from the staff of the Berkeley Journal of Criminal Law and their faculty reviewer Professor Jonathan Simon. 
a. The Founding Article 124

b. Broken Windows in Vogue 127

c. Police Misconduct in a Broken Windows City

d. The Future of New York Policing.

II. Thesis 132

III. Analysis. 133

A. The Perils of Instrumentalism.............................................. 133

1. Law and Legality in Broken Windows Theory ............... 133

2. Lessons from Varieties of Police Behavior 135

B. Some Surprising Fruit of Legalism

C. A Note on Value and Criterion in Policing........................... 143

D. Legalism and Aggressive Policing .................................... 146

IV. Conclusion

Today, there is a family of police strategies that teach the importance of cracking down on petty crime and urban nuisance as the key to effective crime control. Under the "broken windows" appellation, this strategy is linked in the public mind with New York City and the alleged successes of its police department in reducing the rate of crime over the past two decades. This article is critical of such order maintenance approaches to policing: I argue that infringements of civil liberties by such departments could be reduced if the departments looked at law more as a good to be served for its own sake and less as an instrument for the promotion of order. In other words, a shot of legalism is the correct medicine to reduce police misconduct that pierces the law's protections of citizen freedom.

The Article begins by distinguishing law and order as goals of the police and by introducing the concept of a spectrum between legalism and instrumentalism along which any department can be placed. The Article then switches direction-launching into a lengthy background section on the work of James Q. Wilson and the history of the order maintenance movement in policing. Although this section is billed as background, the interpretation of Wilson's work is at the heart of the Article's argument.

Wilson wrote two works of great influence on the study and practice of American policing: his sociological book, Varieties of Police Behavior, and Broken Windows, a popular magazine article coauthored with James Kelling. Varieties of Police Behavior was an empirical work, albeit one built more on observations and interviews than on statistics. Written in a lively style, the book is full of candid understanding about 
policing, including the insight that the work of the police has always been not simply about law enforcement, but about maintaining social order as well. Written years later, Broken Windows was an advisory piece for a lay audience. Wilson argued that police should concentrate on order maintenance in order to solve problems of urban crime and decay. Essentially, the Broken Windows article embodied normative conclusions that Wilson drew from his observations in Varieties of Police Behavior.

My work in this Article represents a normative path not taken from the threshold of Varieties of Police Behavior. In Section I, I offer important background information, using the idea of a spectrum between legalism and instrumentalism to present a novel reading of the literature on order maintenance policing. With this foundation established, Section II presents prescriptions for policing that differ drastically from Wilson's own. In Section III, I support those prescriptions with two reasons to believe that increased legalism will reduce civil libertiesrelated misconduct: (1) officers will be more averse to breaking the law themselves and (2) a lid is placed on police aggression by imposing a more limited conception of what is properly a police matter. Finally, Section IV revisits the Article's relationship to Wilson's work and concludes with a bookend summary.

\section{BACKGROUND}

\section{A. Distinguishing Law and Order as Objectives of the Police}

We take it for granted that the mission of the police is to uphold "law and order." The phrase itself is so common as to have become idiomatic: it is used to describe the style of every fresh mayoral candidate who vows to "clean up the streets" and to "get tough on crime." Through such usage, the two concepts denoted by the component nouns are obscured and conflated. "Law" and "order" are two distinct ideas and two distinct goals that a police department might possess.

A society is lawful where its people conform their conduct to the law. We have evidence of a lawful society where, on a little-trafficked German street, the pedestrians wait for a signal to cross at the intersection. The law prohibits jaywalking, and a high level of compliance with its dictates is observed. Now imagine the same street in which the pedestrians are all waiting for the signal, but when the walk sign appears, some begin to skip, others cartwheel, and a few couples 
grab hold of each other and tango across the intersection. Assuming that it is not against the law to practice ballroom dance in a public way, all of these people are acting in conformity with the law. Again, we have evidence of a lawful society, but not necessarily an orderly society. It is disorderly because the pedestrians' conduct is unpatterned and irregular.

Further, consider Rio de Janeiro during Carnival. The crowds of revelers are anything but orderly. There is little regularity or predictability to their conduct. At the same time, while I do not doubt that the festival is plagued with a regrettable share of crime, this disorder is not in principle incompatible with a high degree of lawfulness. If one imagines that the people of Rio live under a liberal legal regime, then the chaos per se is not unlawful.

A society can also be orderly without being lawful. A lynch mob is usually a chaotic affair, but there may have been cases (and we can certainly envision the cases) where lynching proceeded in a structured, systematic fashion. For example, the authorities may habitually permit an organized group of citizens to take prisoners from their custody. In this scenario, extralegal killing proceeds in an orderly manner. Consider as well the apocryphal notion that the trains ran on time in Mussolini's Italy. This regularity is the hallmark of an orderly society, and yet, we would be wrong to say that fascist Italy was a lawful society. Quite the opposite, it was exceedingly lawless since state fiat and party repression had displaced the rule of law.

Police help society by maintaining both law and order. When a police officer tickets a speeder or arrests a robber, she advances law by both correcting the conduct of the individual and deterring other violators. It is also plausible to say that a society is more lawful when those who break the law are punished as the law prescribes. As for order, a police officer supports it both when she is enforcing the law and when she is not. In the latter category, think of a police officer directing traffic around the arena after a basketball game. For the former category, consider a police officer warning or ticketing a driver who is trying to bypass traffic by traveling in the highway shoulder. Driving on the shoulder may be unlawful, but it is also highly disorderly. The officer who disciplines the driver combats both failures.

An executive organization charged with responsibility for enforcing a body of law, like the police, may usefully be described in terms of its attitude towards the law that it enforces. Organizations can be situated along a spectrum. At one terminal is an instrumental attitude toward law, where law is viewed as a means to the achievement of a 
collateral policy goal. At the other terminal is a legalistic attitude, where law is viewed as an end in itself. For the police, having an instrumental attitude means that the law is of importance only to the extent that it serves or constrains the pursuit of their collateral policy goal. This could be order, as we have been discussing, or perhaps safety. The collateral policy goal will vary depending on the organization. Just like the police are concerned with both law and order, an administrative agency like the EPA is concerned with both upholding the law (the Clean Air Act, the Clean Water Act, etc.) and promoting human health. Hypothetically, if the EPA fell at the instrumental end of the spectrum, it would regard the statutes in its bailiwick as simply either tools or obstacles to achieving its goal of protecting human health.

\section{B. James Q. Wilson: Police Styles and Broken Windows}

\section{The Concept of Police Style}

James Q. Wilson, a Harvard sociologist, wrote the classic empirical work on the differences in how police in diverse departments do their jobs. ${ }^{1}$ Wilson and his assistants studied the work of police in eight cities, utilizing some statistics compiled from departmental data but primarily relying on a large collection of anecdotes and observations developed by observing and interviewing citizens and officers in the communities studied. ${ }^{2}$ In his work, Wilson concluded that the departments he studied could be described as having one of three styles: Watchman, Legalistic, and Service.

I will contend that Wilson's Watchman and Legalistic styles map interestingly onto the spectrum between legalism and instrumentalism I describe. Before I explain, however, I will say more about Wilson's concept of a police style.

What Wilson calls "police style" is an organizational phenomenon dictated by the administrator of the department. ${ }^{3}$ The differences between departments that make for a style are "animate[d] and sustaine[d]" by "departmental polices and organizational codes," and these are matters typically under the control of the police chief, as opposed to even the chief's formal superiors in the city administration. ${ }^{4}$ Significantly, to say that an individual officer holds to the Legalistic

\footnotetext{
JAMEs Q. WILSON, VARIETIES OF POLICE BeHAVIOR (1968).

See id. at 13-14 (describing methodology).

See id. at 83, 179-80.

Id. at 83; see also id. at 179-80, 227-28, 232-33.
} 
style or the Watchman style would be a misappropriation of terms: Wilson's concept of style pertains to departments and not to individuals. ${ }^{5}$ However, style does manifest in the behavior of officers, and more specifically, in the way they handle the significant discretion vested in them. ${ }^{6}$ Examples of use of discretion to which Wilson paid particular attention were: inter alia, treatment of juveniles, issuance of parking tickets, and response to drunks. In these situations, police can often choose among arresting, intervening informally, or ignoring the behavior. $^{7}$ What choice the officers of a department tend to make in certain situations is a function of the department's style. ${ }^{8}$

Note that, implicit in Wilson's reasoning, is the idea that organizational policy set at the top is capable of influencing officer behavior on the streets in the ways Wilson associates with style. The exact relationship between formal policy decisions and officer conduct is a significant question, and the reader would be right to wonder whether the connections asserted by Wilson hold true. At least one scholar has undertaken additional quantitative research in an effort to validate the position of Varieties of Police Behavior. To wit, Jeffrey Slovak sought to test the claim that organizational-level variables were determinants of patterns of officer activity. ${ }^{9}$ Relying on data derived from police dispatch logs, Slovak discovered that Wilson's model largely held true. ${ }^{10}$ Even when compared to the particular urban environment in which a department operates, Slovak found that internal, organizational dynamics were the principal drivers of how proactive and how legalistic officers were in carrying on their work. ${ }^{11}$ As summarized in his conclusions, "There is relatively little of situational determinism here, but relatively much of pragmatic, rational, organizationally chosen action."12

More broadly, belief in the efficacy of administrative factors is

See id. at $179-80$.

See id. at 83 (introducing a chapter on discretion and its measurement that is the basis for Wilson's generalizations about style).

7 See id. at 84.

8 See id. at 138-39 ("The police administrator must decide what steps he will take to affect the way in which his officers use the discretion they have in the four cases described in this chapter.”).

9 See JefFrey S. SlovaK, Styles of Urban Policing 11-14 (1986).

10 See id. at 12-14 (outlining the research project).

11 Id. at 170.

12 Id. (emphasis added). 
supported by general research in the theory of organizations. ${ }^{13}$ This is the conclusion of Barbarba Armacost, a policing scholar, in her review of the literature. Armacost relies in large measure on the work of V. Lee Hamilton and Joseph Sanders, who both argued that institutional roles strongly shape the perceptions and decisions of individual actors placed in those roles, at least insofar as the individuals do not rebel against the authority above them. ${ }^{14}$ The result is the substitution of the individual's preferred mode of analyzing a problem with that dictated by her institutional position. ${ }^{15}$ As Armacost summarizes, "The key insight here is that individuals who are embedded in organizations do not make choices solely as individuals." 16

Police style as an organizational phenomenon can be distinguished from the thinking of individual police officers about their work. Indeed, Wilson claimed that the views police express about their work are largely the same regardless of the style of their department. ${ }^{17}$ In every department, the administrators "devise the policies, manipulate the rewards and sanctions that get them carried out, and reflect on their justification.” ${ }^{18}$ Patrolmen, on the other hand, are always busy with the tasks before them: "making runs, stopping cars, filling out forms, and putting up with citizen behavior that is tedious, bizarre or even dangerous." ${ }^{19}$ When they do reflect about their jobs, their views are the same regardless of whether they are in Watchman or Legalistic departments. $^{20}$

The commonalities amongst officers that Wilson observed are what Armacost would call "occupational culture" as opposed to “organizational culture.”21 Her characterization of occupational culture is cognate with Wilson's thinking. Like him, she traces the uniformities that constitute police occupational culture to a shared quotidian of mundane and stressful tasks. To use her words, occupational culture "is

\footnotetext{
13 See Barbara E. Armacost, Organizational Culture and Police Misconduct, 72 GEO. WASH. L. REV. 453, 507-10 (2004).

14 Id. at 508 (citing V. Lee Hamilton \& Joseph Sanders, Responsibility and Risk in Organizational Crimes of Obedience, 14 REs. ORG. BEHAV. 49, 57, 63 (1992)).

15 Id. (citing Hamilton \& Sanders, supra note 14, at 49, 57).

16 Id. at 509 (alteration in original) (quoting Hamilton \& Sanders, supra note 14, at 66).

17 Wilson, supra note 1 , at 179-80.

18 Id. at 179.

19 Id.

20 Id. at 179-80.

21 Armacost, supra note 13, at 494.
} 
created by the kind of work that law enforcement officers do."22 On the other hand, what Armacost refers to as "organizational culture" differs from department to department and aligns conceptually with police style. $^{23}$ In sum, whilst police may possess a uniform occupational culture, individual departments vary in their organizational culture, viz., their police style, and on Wilson's model, it is the "police administrators [who] effect the difference between these police styles."24

\section{The Watchman and Legalistic Styles}

Wilson's Watchman and Legalistic styles are of special interest for the contrast their juxtaposition illustrates between instrumental and legalistic attitudes toward the law. As the following summaries of each style aim to show, the Watchman style embodies an attitude towards the law falling on the instrumental side of the spectrum, while the Legalistic style, unsurprisingly, exemplifies an attitude resting nearer the legalistic end. It should be recognized at the outset though that the concept of a spectrum between instrumentalism and legalism that I introduce in this Article is distinct from Wilson's notion of police style. As such, not all of the features that Wilson attributes to Watchman or Legalistic departments necessarily pertain to a department on the instrumental or legalistic side of the spectrum.

It is a basic assumption of the Watchman style that police need not be preoccupied with enforcing the law. In light of the fact that "law enforcement" is now a common synonym for "police," this may seem counterintuitive to the contemporary reader. Wilson writes, "In some communities, the police in dealing with situations that do not involve 'serious' crime act as if order maintenance rather than law enforcement were their principal function." 25 To be sure, the police in these communities are not unconcerned with enforcing the law; where they can apprehend the perpetrator, policemen in Watchman departments can be counted on to arrest, book, and jail bank robbers or murderers. ${ }^{26}$ Yet

22 Id. at 494.

23 Id. ("[O]rganizational culture [means] the formal and informal values, norms, and ideas that characterize and define a particular institution, for example, a particular police agency such as the LAPD.”) (citing Robert W. Worden, The Causes of Police Brutality, in Police Violence: Understanding and Controlling Police Abuse of ForCE 23, 28-31 (William A. Geller \& Hans Toch eds., 1996)).

24 WiLsON, supra note 1 , at 180.

25 Id. at 140.

26 See id. at 141 ("Serious crimes, of course, should be dealt with seriously.”). 
notwithstanding, there are many cases where an officer in a Watchman department will choose to ignore illegality or handle it without taking the formal step of arresting a citizen or issuing a citation. ${ }^{27}$ Equally true, there are cases when such an officer acts to fix a problem that the law considers minor, does not deem a problem at all, or at least would not consider a problem were it in a more reformed, rigorous condition. ${ }^{28}$

However counterintuitive the above description of a police department may be, the Watchman style is the older tradition in American policing. Early American police in cities like Boston were first and foremost watchmen, part-time workers hired to "keep the streets clear of obstructions, human and material, and to supervise a number of ordinances pertaining to health, lighting, and animals running loose." ${ }^{29}$ The crimes they dealt with were matters like "[v]agabondage, raucous behavior, public lewdness, and street fights." ${ }^{30}$ What we might think of as "real crime" was left up to private redress: victimized citizens who could identify a thief or attacker could initiate prosecution by applying for a warrant and paying an officer of the court, the constable, to serve it for a fee. ${ }^{31}$ As Wilson tells us, "As late as 1863, a Boston alderman, the aristocratic Thomas Coffin Armory . . . proclaimed: 'It is the duty of the police officer to serve ... warrants, when directed to him. It is nowhere made his duty to initiate prosecutions.", 32

Wilson's Watchman departments remain true to this tradition in three respects: a focus on order, relative passivity, and lack of professionalization. To carry out his order maintenance role, "the patrolman is expected to ignore the 'little stuff' but to 'be tough' where it is important." ${ }^{33}$ For instance, a brawling, unruly, or drunken adult is

27 See, e.g., id. ("Juveniles are 'expected' to misbehave, and thus infractions among this group-unless they are serious or committed by a 'wise guy'—are best ignored or treated informally.").

28 See, e.g., id. at 142 (listing "creating a disturbance in a restaurant, bothering passersby on a sidewalk, [and] insulting an officer" as instances where an "officer is expected to restore order"). The oblique reference to law "in a more rigorous, reformed condition" is meant to capture the fact that, in the absence of vague laws against "crimes" like disorderly conduct, vagrancy, or public intoxication-that is to say laws that the police can use as handy catchalls for disfavored conduct-much behavior subject to police control and sanction in a Watchman department would not be colorably unlawful conduct at all.

29 Id. (citing Roger LANe, Policing The City: Boston, 1822-1885 (1967)).

30 Id. (citing LANE, supra note 29).

31 Id. (citing LANE, supra note 29).

32 Id. at 143 (second alteration in original) (quoting LANE, supra note 29, at 130).

33 Id. at 145. 
more likely to be taken home or "pacified on the scene" than he is to be arrested. $^{34}$ Similarly, certain minor infractions by juveniles are simply ignored altogether, while those the police feel they cannot ignore are handled without arrest via the "administ[ration] of a swift kick or a verbal rebuke, hav[ing] the boy do some chores ... or turn[ing] him over to his parents for discipline." ${ }^{35}$ However, sometimes extralegal solutions to problems of order are less merciful. A high-ranking officer in a Watchman department explained to Wilson's interviewer that the police were “" pretty tough on vagrants here,"” that they treat such persons to “"summary justice and send them to jail,"” where they "'rough 'em up a bit and then ... send them out of town.", ${ }^{36}$ Wilson makes explicit what these patterns of behavior bespeak about how a Watchman-like department regards the law:

[T]he penal law is a device empowering the police to maintain order and protect others when a serious infraction has occurred; the exact charge brought against the person is not so importantor rather, it is important mostly in terms of the extent to which that particular section of the law facilitates the uncomplicated exercise of police power and increases the probability of the court sustaining the action. ${ }^{37}$

Police in Watchman departments are relatively passive in that they typically do not proactively pursue criminals but instead respond to disturbances as they occur or act to apprehend serious criminals only as they come to the attention of the police. ${ }^{38}$ Officers follow the path of least resistance, which means minimizing confrontations with the public. ${ }^{39}$ As Slovak later explained, the Watchman style is all about "keeping a lid on things." ${ }^{40}$ Relatedly, the police in Wilson's Watchman departments tended to be poorly paid and underprofessionalized. ${ }^{41}$ Patrolmen usually did not have more than a high school education and received such meager wages that they were expected to maintain second

34 Id. at 146.

5 Id. at 145.

36 Id. at 147.

Id. at $144-45$.

38 See id. at 144, 148 ("[T] restore order.”).

39 Id. at 144.

40 SLOVAK, supra note 9, at 112.

41 WiLSON, supra note 1 , at 151-58. 
jobs. ${ }^{42}$ Training was also quite limited, and there was a dearth of written rules, records, and standardized procedures. ${ }^{43}$

Ultimately, these last two characteristics of the Watchman department, passivity and underprofessionalization, are not important to my thesis insofar as they do not bear on where a department stands on the instrumental-legalistic spectrum. I present them to the reader to give the flavor of a Watchman department and so that he or she will not confuse and conflate the Watchman departments of the 1960s with the modern order maintenance departments to which they will be compared as the Article continues.

If the Watchman departments harkened back to the early days of American policing, then the Legalistic departments Wilson studied were oriented to the future. At the time of Wilson's study, the Legalistic approach was associated with reform and change. ${ }^{44}$ As such, in addition to their characteristic focus on law enforcement rather than order maintenance, Legalistic departments exhibited a refined professionalism and a systematic, proactive approach to the business of policing.

Legalistic departments are much more systematic and professional in their approach to their work than their Watchman counterparts. Under a Legalistic regime, precinct stations are abolished and replaced with a centralized headquarters, new specialized departments are instituted (including departments dedicated to research and planning and internal affairs), training requirements are magnified, and the individual officer is expected to cope with a barrage of new reports and paperwork. ${ }^{45}$ "A patrolman driving a beat in Oakland [a Legalistic city] carries with him a fat briefcase filled with forms and notebooks on which he records every kind of investigation, complaint, report, and 'field interrogation.",46 A premium is also placed on attracting college educated recruits, using the latest technology, and achieving a technical, bureaucratic efficiency. ${ }^{47} \mathrm{~A}$ result of all this standardization and systematization is that the police leadership can effectively reorient the police to be more aggressive in enforcing the law. ${ }^{48}$ Police are expected to be highly energetic in responding to citizen

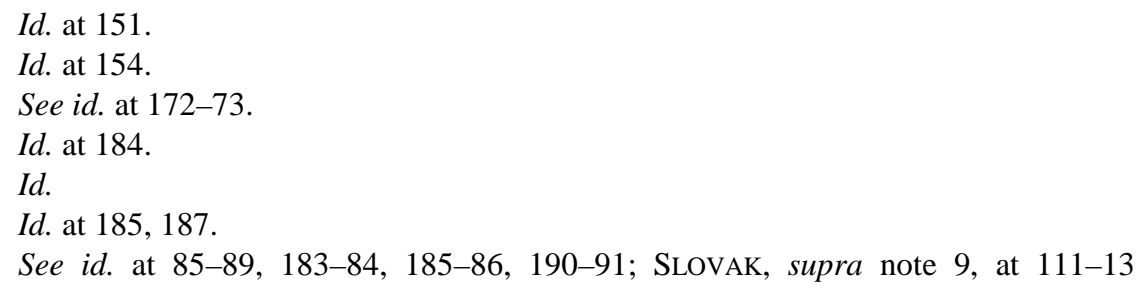


reports of unlawful activity and highly proactive themselves in arresting observed violators, even where no one is complaining about the illicit happenings. $^{49}$

True to its name, a Legalistic department presents a preference for arrests and tickets and a tendency to treat the law as the sine qua non of what is a police matter. "[T]he police administrator uses such control as he has over the patrolmen's behavior to induce them to handle commonplace situations as if they were matters of law enforcement rather than order maintenance." 50 This means that a high rate of traffic tickets will be issued, a higher proportion of juvenile offenders will be bureaucratically processed and arrested, vice will be hounded, and a large number of arrests for misdemeanors will be made, "even when, as with petty larceny, the public order has not been breached." ${ }^{51}$ According to Wilson, this stepped up enforcement will often be experienced by those on whom it falls_-”juveniles, Negroes, drunks, and the like”-as harassment. $^{52}$ Indeed, emphasis on law enforcement may bring the police to bother even the more powerful, "decent" members of the community. For example, one Legalistic chief sent a letter to local business owners to complain that they were letting youths buy and smoke cigarettes at their stores in violation of Illinois law. ${ }^{53}$ On the other hand, a businessman committing no crime can feel safe in even a disreputable enterprise: “drug-store pornography," Wilson tells us, "is pretty much left alone" since "the law affords few grounds for an arrest." 54 The phenomena of forbearance in one case and activity in the other are two sides of the same coin. This is illustrated by the following quote from an interviewed sergeant: “'It's Chief X's philosophy that the case is either unfounded or you had better have charged them with the offense which they are suspected of having committed.... Either there's no trouble and no reason to stop them or else you had better bring them in.'”55

Perhaps most strikingly, Wilson found that "the police in a

(emphasizing the association of the Legalistic style with aggressive, proactive policing).

49 See WILSON, supra note 1, at 173-74 (describing arrests of prostitutes and an insistence on prosecuting bad-check passers even when the merchant-victim has no interest in doing so).

50 Id. at 172.

51 Id.

52 Id.

53 Id. at 180.

54 Id. at 174.

55 Id. at 177. 
legalistic city obey the law themselves." ${ }^{56}$ Where the parking lot was across the street from the police headquarters, the most direct route would have required officers to jaywalk. ${ }^{57}$ Nevertheless, Wilson's interviewers observed officers routinely walking to the corner and waiting for the light to cross at shift changes. ${ }^{58}$ An interviewer recorded a patrolman who admitted to dashing across the street "“[o]nce or twice,"” but who said “"you get used to not jaywalking, and that's the way it is all the time." 59

\section{From the Watchman Style to Broken Windows}

\section{a. The Founding Article}

In the years that followed the publication of Varieties of Police Behavior, the momentum in American policing carried cities in the direction of Wilson's Legalistic departments. The officer who drives his beat and carries a briefcase full of forms with him was the increasingly present future of policing. Using different terminology, Samuel Walker refers to this phenomenon as the "professionalism movement." ${ }^{60} \mathrm{He}$ says of it, "The reform agenda of the professionalism movement included expert leadership, freedom from external (especially political) influence, the application of the principles of modern management to police organizations, and elevation of personnel standards, both through higher entry standards and better training., ${ }^{61}$ In observing his Legalistic departments, Wilson was witnessing a movement in policing that in the years following would become an ever more dominant paradigm for police chiefs. $^{62}$

More than a decade after Varieties of Police Behavior, Wilson, along with his Atlantic monthly co-writer, George Kelling, sounded an

Id. at 180 .

57 Id.

58 Id.

59 Id.

60 Samuel Walker, The New Paradigm of Police Accountability: The U.S. Justice Department "Pattern or Practice" Suits in Context, 22 ST. LouIS U. PUB. L. REV. 3, 11 (2003).

61 Id. (citing Samuel Walker, A Critical History of Police Reform: The EMERgEnCE OF Professionalism (1977) [hereinafter WALKER, A CRITICAl History]).

62 See id. (citing WALKER, A CRITICAL HistORY, supra note 61) (explaining that the "professionalization movement emerged in the early years of the twentieth century" and that a popular book describing the approach became a "bible" for police chiefs of the 1950s through the 1970s). 
alarm that the new model was not working. ${ }^{63}$ They thought the police would be more effective if patrolmen stopped driving around in cars acting like their only business was enforcing the penal law. Pointing to successes observed in New Jersey, where officers left their cars and returned to walking beats, Wilson and Kelling argued that policing needed a renewed focus on order maintenance. ${ }^{64}$ In significant measure, this meant a return to behaviors typical of Wilson's Watchman departments. By cracking down on sources of disorder-"disreputable or obstreperous or unpredictable people: panhandlers, drunks, addicts, rowdy teenagers, prostitutes, loiterers, and the mentally disturbed"police on foot could make neighborhoods safer. ${ }^{65}$ This was both because such urban ills were themselves a significant source of fear and distress for city dwellers and because the disorder was criminogenic. ${ }^{66}$

In sum, disorderly behavior-low-level crime and non-crimewas not just unsightly, unpleasant, and frightful, but it was a cause of more serious, violent crime. $^{67}$ Wilson and Kelling explain, "Social psychologists and police officers tend to agree that if a window in a building is broken and is left unrepaired, all the rest of the windows will soon be broken."68 Per the same principle, a neighborhood that is plagued with vandalism, prostitution, obstreperous drunks, rowdy youths, unstable homeless persons, or aggressive panhandlers is a neighborhood ripe for a rise in more serious crimes. What has happened in such a neighborhood is a breakdown of community order, of the informal social controls that ordinarily keep drunks from bothering "decent" people and brazen teenagers from menacing those who pass by "their" corner. ${ }^{69}$ When these social controls disappear, people of the neighborhood are no longer "confident they can regulate public behavior by informal controls." 70 Consequently, the area becomes a place where drugs are sold and cars are stripped, a place where the drunks who congregate are "rolled" by rowdy juveniles, the johns who visit the prostitutes are targeted for robbery, and anyone outside is at risk of

63 James Q. Wilson \& George L. Kelling, Broken Windows, ATLANTIC MonTHLY, Mar. 1982, at 29.

64 Id. at 29-30.

65 Id. at 30.

66 Id. at 31.

67 Id.

68 Id.

69 Id. at 31-32.

70 Id. at 32. 
being mugged. ${ }^{71}$

Police can preempt this vicious circle only if they return to certain behaviors characteristic of the Watchman style. Kelling walked the streets with a Newark foot-patrolman named Kelly and discovered how Kelly's Watchman-like use of authority reinforced community norms that might otherwise break down. ${ }^{72}$ The standards in question were, of course, not legal norms but norms recognized by the "regulars" in the neighborhood, a category that included both "decent folks" and those familiar local drunks and derelicts who accepted the rules. ${ }^{73}$ Kelly and the regulars were well-acquainted with each other and with the standards that he aimed to enforce:

Drunks and addicts could sit on the stoops, but could not lie down. Talking to, bothering, or begging from people waiting at the bus stop was strictly forbidden. If a dispute erupted between a businessman and a customer, the businessman was assumed to be right, especially if the customer was a stranger. If a stranger loitered, Kelly would ask him if he had any means of support and what his business was; if he gave unsatisfactory answers, he was sent on his way. Persons who broke the informal rules, especially those who bothered people waiting at bus stops, were arrested for vagrancy. Noisy teenagers were told to keep quiet. ${ }^{74}$

Kelly was not the sole author of these rules; their creation was a joint project with the regulars. ${ }^{75}$ When someone broke the rules, residents turned to him to restore order and assisted by heaping ridicule on violators. ${ }^{76}$ Moreover, like the policemen of Wilson's Watchman departments, Kelly's methods of restoring order frequently strayed outside the bounds of the law. ${ }^{77}$ As the authors described his methods, "Some of the things he did probably would not withstand legal challenge."78

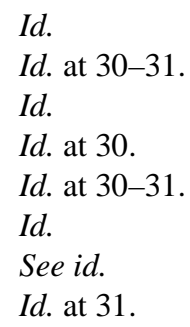




\section{b. Broken Windows in Vogue}

Today, the theory that disorder begets crime is so associated with Wilson and Kelling's metaphor that the phrase "broken windows" is roughly synonymous with order maintenance approaches to policing. It is equally true that no city is more identified with "broken windows theory" than New York City. As documented by Kelling himself (this time with Catherine Coles as his writing partner), the 1990s New York Police Department responded to high crime and spotty quality of life with order maintenance rather than law enforcement. ${ }^{79}$ The chief protagonists in the struggle were Mayor Rudy Giuliani, Police Commissioner Raymond Kelly, and his successor, William Bratton. ${ }^{80}$ Under their watch, victories were achieved against squeegeeing, graffiti, and aggressive panhandling ${ }^{81}$ - the kinds of urban ills that Wilson and Kelling had found so baleful when left uncontrolled. Though Kelling and Coles were writing in 1996, a relatively early point in this campaign, ${ }^{82}$ they could already point to statistics showing a declining crime rate in the City. ${ }^{83}$ They linked that evidence to the new broken windows approach. ${ }^{84}$

Bernard Harcourt, a critic of the New York policies that Kelling and Coles laud, documents the large increase in both misdemeanor arrests and use of "stop-and-frisk" that accompanied the NYPD's order maintenance push..$^{85}$ Despite the fact that the number of misdemeanor complaints remained static, the number of misdemeanor arrests in New York City jumped by over fifty percent in the three years between 1993 and 1996, ${ }^{86}$ the period Kelling and Coles associate with the turn to order maintenance. At the same time, the NYPD greatly expanded its use of stop-and-frisk, ${ }^{87}$ a tactic of stopping, questioning, and sometimes patting down citizens in public places. The tactic purports to use investigatory

79 George L. Kelling \& Catherine M. Coles, Fixing BroKen Windows 137-56 (1996).

80 See id. at 141, 143.

81 Id. at $141,149$.

${ }^{82}$ See id. at 141-43 (describing the 1993 anti-squeegeeing campaign as "The First NYPD Success").

83 Id. at $151-56$.

84 Id.

85 Bernard E. Harcourt, Illusion of Order: The False Promise of Broken WiNDOWS POLICING 10 (2001).

${ }^{86}$ Id.

87 Id. 
authority recognized by Terry $v$. Ohio ${ }^{88}$ and New York statute, ${ }^{89}$ both of which permit officers to stop individuals in public on reasonable suspicion of criminality and to conduct a limited search for weapons ("frisk" or "Terry pat") where a reasonable suspicion exists that the detained individual is armed and dangerous.

Just like the routing of the squeegee men, the increase in misdemeanor arrests and use of stop-and-frisk is in keeping with Wilson and Kelling's order maintenance theories. The penal law, they originally noted, lists offenses that can be used as tools for police in their efforts to keep order, independent of their significance as laws to be enforced for their own sake. ${ }^{90}$ Laws against vagrancy or public drunkenness are much more valuable for what they enable the police to accomplish-arrest and summary discipline ${ }^{91}$ of a public order malefactor - than their value as crimes to be prosecuted. ${ }^{92}$ Unsurprisingly, when a department turns to order maintenance, increased figures for misdemeanor arrests are to be expected. In like manner, we can anticipate police will make use of their authority under Terry to further the aim of order. Each stop is valuable, not solely as an opportunity to investigate a particular crime of which the individual stopped was suspected, but as a general opportunity to assert police authority and stay in contact with citizens. ${ }^{93}$

Looking to the foregoing, I take the contemporary NYPD to be characteristic of the modern order maintenance department. Indeed, it would be difficult not to belabor the connections between the theoretical approach of Wilson and Kelling and the contemporary manner of policing in New York City. This is not to say that the NYPD or any

88392 U.S. 1 (1968).

89 N.Y. CRIM. Proc. LAW § 140.50 (McKinney 2010).

90 Wilson \& Kelling, supra note 63, at 35.

91 Harcourt describes how arduous a misdemeanor arrest can be even when the matter does not culminate in conviction. HARCOURT, supra note 85, at 176 . He reminds us that arrests create a criminal record, id., that arrestees are " [h] $[\mathrm{h}]$ andcuffed, fingerprinted and often strip-searched,'” id. (quoting Matthew Purdy, In New York, Handcuffs Are OneSize-Fits-All, N.Y. TimES, Aug. 24, 1997, at A1), and that, per a newspaper report, "'some people were held in cells for more than 60 hours waiting to see a judge for crimes like farebeating, sleeping on park benches, and drinking beer in public.”' Id. (quoting Michael Cooper, You're Under Arrest, N.Y. Times, Dec. 1, 1996, § 13, at 1).

92 See Wilson \& Kelling, supra note 63, at 35.

93 See HARCOURT, supra note 85, at 10-11 ("The fact is, even if the quality-of-life initiative contributed to some degree to the decline in crime in New York City, the primary mechanism is probably not the broken windows theory. The primary engine is probably the enhanced power of surveillance offered by a policy of aggressive stops and frisks and misdemeanor arrests.”). 
other modern department we might label as order maintenance corresponds in every particular with the model the authors propounded in the Atlantic Monthly. It does mean, however, that the police are approaching their mission in a way that comports more with a goal of order maintenance and less with one of law enforcement. Increased use of the power to arrest for misdemeanors and to stop-and-frisk are some tell-tale behaviors that result.

The aroma of the old Watchman style departments stands around modern-day order maintenance tactics. For example, the use of minor misdemeanors as order maintenance tools is a theme that runs right through Wilson's chapter on Watchman departments in Varieties of Police Behavior, to the pages of the Atlantic Monthly, and on into modern NYPD practice as documented by Harcourt, Kelling, and Coles. Nevertheless, it must be remembered that a Watchman department, the kind of police work advocated in Broken Windows, and the modern NYPD are three different things. In many respects, the contemporary NYPD is still much more like one of Wilson's Legalistic departments than it is one of his Watchman institutions. The Watchman departments were characterized not only by a focus on order maintenance but also by passivity and lack of systematization or professionalism. Legalistic departments, in contrast, were not just oriented towards law enforcement; they were also keen on using the latest technology, relying on detailed written rules, producing vast numbers of written reports, hiring the best officers, training them rigorously, and taking a proactive approach to doing their jobs. Without regard to the turn to order maintenance, I assume it to be true that today's NYPD is like a Legalistic department, not a Watchman organization, in each of these respects. $^{94}$

\section{c. Police Misconduct in a Broken Windows City}

During the last two decades, New York City was blessed with a falling crime rate, a phenomenon that some attributed to its adoption of

94 There is also the possibility of fragmentation in a department on the scale of the NYPD. Different divisions may have different police styles, a circumstance that Wilson himself did not recognize. In the NYPD, detectives in homicide or vice may still appear much like Wilson's Oakland cops, continuing to display the expertise and law enforcement focus typical of the professionalism movement in the midst of the trumpeting of broken windows by the brass. On the other hand, certain patrol officers who have been restored to walking beats may exemplify the new order maintenance philosophy that the public has come to associate with New York policing. 
broken windows policing. ${ }^{95}$ Observing these trends in 1996, Kelling and Coles believed that the drop in crime could be traced to the new police tactics. ${ }^{96}$ For present purposes, it suffices to say that not everyone who has considered the issue has reached the same conclusion. Indeed, much evidence casts doubt on any causal relationship between the two changes. ${ }^{97}$

Apart from attacking its effectiveness at reducing crime, critics of the new style of policing have pointed to violations of civil liberties under the new policing regime. Anecdotes and statistics alike attest to the alarming frequency at which police infringe citizens' rights in today's New York.

Harcourt recounts the story of Chris C., a New York man who was "[l]ooking for a friend's name on the mailbox in the lobby of an apartment building" when he was arrested by officers who were "hunting for drug activity." 98 Chris was accused of trespass, "handcuffed, taken to jail, strip-searched, and held for nineteen hours" only to have his case dismissed. ${ }^{99}$ A woman named Nancy T., was driving in Chinatown when she was stopped and arrested "for driving without her license and talking back to a police officer," or “'failure to comply with an order." "100 Nancy was also handcuffed, brought to the station house, strip-searched, and kept in custody until early the next morning. ${ }^{101}$ In another story, a middle-aged African-American woman was walking home from work one night. ${ }^{102}$ Noticing an out-of-place

95 E.g., Christina Nifong, One Man's Theory is Cutting Crime in Urban Streets, CHRISTIAN SCI. MONITOR, Feb. 18, 1997, at 1.

96 KeLling \& COLES, supra note 79, at 151-56.

97 E.g., Bernard E. Harcourt \& Jens Ludwig, Broken Windows: New Evidence from New York City and a Five-City Social Experiment, 73 U. CHI. L. REV. 271, 315 (2006) ("Our analysis provides no empirical evidence to support the view that shifting police towards minor disorder offenses would improve the efficiency of police spending and reduce violent crime.”); Steven D. Levitt, Understanding Why Crime Fell in the 1990s: Four Factors that Explain the Decline and Six that Do Not, J. ECON. PERSP., Winter 2004, at 163, 186 (rejecting altered police tactics as an explanation of falling crime rates in the 1990s in favor of "increased incarceration, more police, the decline of crack, and legalized abortion”).

98 HARCOURT, supra note 85, at 177 (citing Purdy, supra note 91).

99 Id. (citing Purdy, supra note 91).

100 Id. (citing Deborah Sontag \& Dan Barry, Challenge to Authority: Disrespect as Catalyst for Brutality, N.Y. TimES, Nov. 19, 1997, at A1).

101 Id. (citing Sontag \& Barry, supra note 100).

102 Id. (citing Eliot Spitzer, The NeW York City Police DePartment's "STOP AND Frisk” Practices: A Report to the People of the State of New York from the 
white man in her mostly black Brooklyn neighborhood, she started to worry and walked faster. ${ }^{103}$ When the man caught up with her, he put his arm around her neck and told her to be quiet, that he was a police officer. ${ }^{104}$ The man forced her back to a waiting car where he and another officer made her put her hands on the car's hood, frisked her, and "conducted a full search of her person" before they told her that she was free to go. ${ }^{105}$

The picture painted by these individual narratives of police intrusion on civil liberties matches data compiled by the New York Civil Liberties Union on stop-and-frisk in New York City. ${ }^{106}$ According to a 2012 report, the number of stops in the city more than quintupled in less than ten years, rising from 97,296 in 2002 to 685,724 in 2011. ${ }^{107}$ Of those 685,724 stops, $86.6 \%$ were black or Latino men. ${ }^{108}$ Indeed, so many young black men were stopped that in just one year, the number of such stops exceeded the number of young black men living in all of the five boroughs! ${ }^{109}$ Further troubling data indicated that, even though police are supposed to have a reasonable belief that the person they have stopped is armed and dangerous before conducting a frisk, 55.7\% of persons stopped were frisked, with searches yielding a weapon only $1.9 \%$ of the time. ${ }^{110}$ Apart from the overuse of frisks, a very large number of putatively innocent people are subject to stops, a fact that casts doubt on whether many of the stops even meet the Constitution's lenient reasonable suspicion standard: “Of the 685,724 stops in 2011, 605,328 were of people who had engaged in no unlawful behavior as evidenced by the fact they were not issued a summons nor arrested."111 This is just a sampling of the worrisome statistics from the report as it pertains to the Fourteenth and Fourth Amendment Rights of New Yorkers.

OFFICE OF THE ATTORNEY GENERAL 78-79 (1999)).

103 Id. (citing SPITZER, supra note 102, at 78-79).

104 Id. (citing SPITZER, supra note 102, at 78-79).

105 Id. (citing SPITZER, supra note 102, at 78-79).

106 See Stop-and-Frisk 2011: NYCLU Briefing, NYCLU (May 9, 2012), http://www.nyclu.org/files/publications/ NYCLU_2011_Stop-and-Frisk_Report.pdf.

107 Id. at 3.

108 Id. at 5.

109 Id. at 7.

110 Id. at 2.

111 Id. at 15. 


\section{d. The Future of New York Policing}

This Article was written prior to the inauguration of Bill de Blasio as mayor of New York City and the ruling of Judge Scheindlin on the constituionality of stop-and-frisk in the City. References to the "modern” or “contemporary” New York City Police Department should be understood accordingly.

While both new developments prefigure reform of stop-andfrisk, an assessment of the changes that have taken place so far is outside the scope of this Article. Signficantly, whether the NYPD will retain its order maintenance orientation remains to be seen. That said, I am cautiously optimistic that the flaws in New York City policing that I identify here are changing for the better.

\section{THESIS}

Like the Watchman department before it, a department with an order maintenance orientation will fall on the instrumental side of the legalistic-instrumental spectrum. As the above background has shown, instrumentalism is all but the official motto of the order maintenance movement in policing. Order maintenance theories instruct the police to make something other than law enforcement a priority; consequently, the law is considered only insofar as it helps or inhibits pursuit ${ }^{112}$ of the collateral policy goal, i.e., order. ${ }^{113}$ We have also seen an order maintenance community, New York City, afflicted with police violations of civil liberties. In light of these facts, I contend:

A more legalistic attitude would reduce instances of civil liberties violations in order maintenance departments. This is both because (1) officers in a more legalistic department will be more loath to disobey the

112 Terry is an example of law that can both help and inhibit the work of an order maintenance department. See Terry v. Ohio, 392 U.S. 1 (1968). On the one hand, the case gives officers of the NYPD Constitutional license to implement stop-and-frisk. At the same time, the Terry doctrine creates limits on the use of that authority. Tactically, officers must be chary of these limits lest they stumble into lawsuits and public outcry that might embarrass the order maintenance project. Consequently, the order maintenance department and its officers must be attuned to Terry both as a tool and as an obstacle or pitfall.

113 See supra note 37 and accompanying text. This is not to say that law enforcement disappears altogether as a priority in order maintenance departments. Especially among certain groups of officers like detectives, law enforcement will remain a priority. Where a department stands on the spectrum is, of course, a matter of degree. The claim here is only that adopting order maintenance will place a department closer to the instrumental end of the spectrum. 
law (including the Constitution) themselves and because (2) legalism tempers aggressive tactics by limiting what is considered a "police matter."

When I speak of increased legalism or instrumentalism, I follow Wilson in treating a department's position on the spectrum as an organizational variable, set by administrators, that manifests in officers' behavior but not necessarily in their expressed views about their jobs. ${ }^{114}$ Tracking Wilson in this manner allows me both to draw support from his findings on the significance of organizational "style" for police behavior and to frame my arguments in terms of critical analysis and redeployment of his theories.

\section{ANALySIS}

\section{A. The Perils of Instrumentalism}

In this section, I aim to demonstrate how an instrumental attitude towards law engenders civil liberties violations by expanding the scope of what is considered a police matter. The basic idea is that where police see their role as keepers of order rather than as enforcers of the law, they expand the range of citizen conduct upon which they are likely to bring to bear their authority. The result is police intrusion on civil liberties, either by the use of authority against the legally innocent, or its use against technically guilty persons against whom the law is invoked only instrumentally. Insofar as the expansion of the police role is a function of instrumentalism, a dose of legalism would naturally diminish these ills.

\section{Law and Legality in Broken Windows Theory}

Wilson and Kelling openly defended order maintenance as a style of policing that strays outside the bounds of legality. Recall their description of the policeman whom Kelling accompanied on his beat, the one who did things that "probably would not withstand a legal challenge." 115 Sometimes the policeman would arrest offenders against neighborhood order for vagrancy, a tactic deployed against those who bothered people at bus stops for example. ${ }^{116}$ Other times, Kelly would "tak[e] informal or extralegal steps to help protect what the neighborhood had decided was the appropriate level of public order,"

114 See supra notes 3-25 and accompanying text.

115 Wilson \& Kelling, supra note 63, at 31.

${ }^{116}$ Id. 
such as telling a loitering stranger to get lost or verbally rebuking rowdy teenagers. ${ }^{117}$

Later in the article, the two admit that charges like vagrancy or public drunkenness possess "scarcely any legal meaning" and that they exist "not because society wants judges to punish vagrants or drunks but because it wants an officer to have the legal tools to remove undesirable persons from a neighborhood when informal efforts to preserve order in the streets have failed." (Here, the authors allude to the long history of this practice, presumably with Wilson's old Watchman departments in mind. ${ }^{118}$ The authors go on to bemoan the movement to clear these statutes from the books. ${ }^{119}$ It is misguided, they say, to deprive police of the authority to make such arrests; those who contend that behavior like homelessness or drunkenness harms no one and therefore should not be criminal fail to see the substantial damages that coalesce when these behaviors go unchecked. ${ }^{120}$

The bluntest description Wilson and Kelling give of police departing from the law in the name of order involves the Robert Taylor Homes, a very large and crime-plagued housing project in Chicago. ${ }^{121}$ Although gangs were a major problem in the Robert Taylor Homes, it was not a crime for gangs to congregate in the halls. ${ }^{122}$ Thus, unless a police officer happenned to be around when a member was committing an offense, he or she could not use arrest as an option for handling the gangs. ${ }^{123}$ The police solution was to "chase known gang members out of the project." ${ }^{124}$ What does it mean to chase them out? The authors quote an officer: "“We kick ass.,"125 In the view of the officers, "the cops and the gangs are the two rival sources of power in the area, and ... the gangs are not going to win." 126

Whatever the salutary effects of the police actions that Wilson and Kelling advocate, these behaviors infringe civil liberties. Arresting a citizen for vagrancy simply to get rid of her is bound to cross constitutional lines. Likewise, commanding a panhandler to get out of a

${ }^{117}$ Id. at $30-31$.

${ }^{118} I d$. at 35.

119 Id.

${ }^{120} \mathrm{Id}$.

${ }^{121} \mathrm{Id}$. at 35 .

${ }^{122} \mathrm{Id}$.

${ }^{123} \mathrm{Id}$.

${ }^{124} \mathrm{Id}$.

125 Id.

${ }^{126}$ Id. 
neighborhood, at least when backed by force or the threat of force, is a use of police authority that cuts through legal boundaries. Choosing to "kick ass" when arrest is not an option is a response to gangs that cannot be reconciled with constitutional limits on police use of force.

All of these uses of police power, and like uses to which the authors only allude, flow from an expanded notion of the police role. Regarding panhandlers, the job is keeping a bus stop orderly and comfortable. With a housing project, the mission is to bring order and safety to its halls and assert the authority of the police vis-à-vis their rivals, the gangs. In each case, the law takes a back seat-it finds itself neglected, exploited, or both. Yet, except for some serious reservations about the potential for stereotyping and discrimination when the police are given free rein, ${ }^{127}$ the authors self-consciously embrace the instrumental turn.

\section{Lessons from Varieties of Police Behavior}

The kind of policing featured in "Broken Windows" exhibits two civil liberties flaws: extra-legal violence and groundless or instrumental arrest. I have argued that both can be traced to an expanded notion of the police role, which is in turn a manifestation of instrumentalism in a police department. This section builds upon this argument by comparing the effects of instrumentalism in Wilson's Watchman departments to the effects of legalism in his Legalistic departments. I will also explore parallels to modern order maintenance departments.

The passivity of officers in a typical Watchman department does not extend to situations where the authority of the police is challenged. Speaking of the Albany police, Wilson wrote, "[T]here is not much evidence of Albany police timidity. A perceived challenge to police authority is met forcefully." ${ }^{28}$ Over an eight-week period in Albany, there were nine persons arrested for disorderly conduct. ${ }^{129}$ In eight of these nine cases, the police report stated that the officer had been the victim of " "abusive language"” or assaulted by the arrestee. ${ }^{130}$ Seven of these arrestees were black, but the eighth was a white man who, when

${ }^{127}$ Id. ("The concern about equity is more serious. We might agree that certain behavior makes one person more undesirable than another but how do we ensure that age or skin color or national origin or harmless mannerisms will not also become the basis for distinguishing the undesirable from the desirable?”).

${ }^{128}$ WILSON, supra note 1 , at 166.

129 Id.

${ }^{130}$ Id. 
witnessing the police arrest someone else, suggested the officer release his target: "“Why don't you let this man go?"”" ${ }^{131}$ When the white man refused to "move on" at the officer's request, he was arrested for disorderly conduct. ${ }^{132}$ In another case, a black man reported being taken to headquarters and beaten on the legs to get an apology for an alleged insult made to an officer. ${ }^{133}$ Wilson recognizes prior research showing that $37 \%$ of officers felt that the police were " “justified in roughing a man up"” when “"he show[ed] disrespect for the police.”"134 Wilson accepts the study's findings with qualification: he suggests that this is typical of some departments, presumably Watchman organizations, but not others, presumably Legalistic ones. ${ }^{135}$

Use of violence and dubious arrests against those who defy officers is matched by similar injuries doled out to strangers, juveniles, and black people. Recall officers in Watchman departments who administered irregular justice to juveniles with a "swift kick" or who beat up vagrants before throwing them out of the city. ${ }^{136}$ Likewise, black males in Albany interviewed by Wilson's assistants recounted stories of informal police violence and insults. ${ }^{137}$ One, who admitted to having been involved with gangs, remembered being "hit frequently by the police” as a youth, but never being arrested. ${ }^{138}$ Another recounted police insults and racial slurs; he spoke of the frustration of not being able to "fight back," presumably for fear of retaliation for challenging the officer's power. ${ }^{139}$

The above descriptions of officer conduct specifically demonstrate connections between abuses and an expanded police role. When the police act as guardians of public order rather than as neutral enforcers of the law, vagrants will be beaten up rather than left alone, raucous juveniles will be kicked rather than ignored or arrested, and citizens will question or oppose officers at their own peril. One must remember that backtalk, being a hobo, and many forms of youthful rowdiness are not crimes. Perhaps most significantly, the law does not

131 Id.

132 Id. at $166-67$.

133 Id. at 167.

${ }^{134}$ Id. at 46 n.44 (quoting William A. Westley, Violence and the Police, 59 AM. J. Soc. 34, 38 (1953)).

135 See id. at 46.

136 See supra notes 35-37 and accompanying text.

137 WiLSON, supra note 1 , at 167.

${ }^{138}$ Id.

139 See id. (“'You can’t stand up and be a man here.’”). 
define police power or police control of the streets as an end in itself. It follows that maintaining authority alone and for its own sake is not a sufficient legal basis for detention or for the use of violence.

Nonetheless, invoking violence and arrest power in order to maintain control - to maintain police-sanctioned order — can be seen in both the old Watchman departments and in contemporary order maintenance departments, such as the NYPD. Harcourt quotes from an interview with an officer in the Bronx:

[Q:] Did you beat people up who you arrested?'

[A:] 'No. We'd just beat people in general. If they're on the street, hanging around drug locations. It was a show of force.'

[Q:] 'Why were these beatings done?'

[A:] 'To show who was in charge. We were in charge, the police.",140

During last year's court challenge to stop-and-frisk, Floyd v. City of New York, ${ }^{141}$ the plaintiffs introduced a recording of a Bedford-Stuyvesant police lieutenant instructing his officers on the importance of controlling the streets:

So we've got to keep the corner clear ... Because if you get too big of a crowd there, you know, ... they're going to think that they own the block. We own the block. They don't own the block, all right? They might live there but we own the block. All right? We own the streets here. You tell them what to do. ${ }^{142}$

In another parallel with the Watchman tradition, modern order maintenance departments utilize misdemeanor arrests as tools of social control. The Floyd plaintiffs introduced a recording of a Bedford

\footnotetext{
140 Harcourt, supra note 85, at 167 (quoting Bob Herbert, Connect the Dots, N.Y. TIMES, Aug. 24, 1997, at D13). Chief Justice Warren recognized the use of stop-andfrisk to assert police control, he wrote of occasions when "the 'stop and frisk' of youths or minority group members is 'motivated by the officers' perceived need to maintain the power image of the beat officer, an aim sometimes accomplished by humiliating anyone who attempts to undermine police control of the streets." "Terry v. Ohio, 392 U.S. 1, 14 n.11 (1968) (quoting LAWRENCE P. TifFANy, DONALD M. MCINTYRE, JR. \& Daniel L. Rotenberg, Detection of Crime: Stopping and Questioning, SEARch AND SEIZURE, ENCOURAGEMENT AND ENTRAPMENT 47-48 (1967)).

141959 F. Supp. 2d 540 (S.D.N.Y. 2013).

${ }^{142}$ Id. at 597 (alteration in original).
} 
Stuyvesant seargeant telling his men:

If you see guys walking down the street, move 'em along. Two or three guys you can move, you can't move 15, all right? If you want to be a[n] asshole or whatever you want to call it, make a move. If they won't move, call me over and lock them up [for disorderly conduct]. No big deal. We could leave them there all night... The less people on the street, the easier our job will be. ${ }^{143}$

The seargeant adds, "If they're on a corner, make them move. They don't want to move, you lock them up. Done deal. You can always articulate later." 144

During a different Brooklyn recording, a deputy inspector instructs officers in terms that imply the identity or merit of the particular charge used to "articulate" why a person is arrested is unimportant: “Tonight is zero tolerance. ... Everybody goes. I don't care ... . They're throwing dice? They all go, promote gambling. I don't care. Let the DA discuss what they're going to do tomorrow." ${ }^{145}$ Here it is worth noting that the commanders' suggested uses for disorderly conduct and gambling charges agree with Wilson and Kelling's defense of using vague misdemeanor offenses to remove public-order malefactors. $^{146}$

Harcourt emphasizes that the NYPD also utilitizes misdemeanor arrests as a tool of surveillance. He writes, "[i]n 1998 the NYPD went even further and began implementing a new policy of detaining anyone arrested for even a minor misdemeanor offense 'until a computerized fingerprint check verifies the person's identity.", 147 In like manner, aggressive use of stop-and-frisk achieves increased surveillance by giving the police an opportunity to challenge, question, and search the person stopped. ${ }^{148}$

143 Id. (alteration in original).

144 Id. at 598 (emphasis omitted).

145 Id. (second and third alterations in original).

146 See supra notes 118-120 and accompanying text.

147 HARCOURT, supra note 85, at 176 (quoting David Kocieniewski \& Michael Cooper, New York Tightens Scrutiny of All Suspects Under Arrest, N.Y. TimES, May 28, 1998, at A1).

${ }^{148}$ See id. at 11 (speaking of the "power of surveillance offered by a policy of aggressive stops and frisks and misdemeanor arrests”). Harcourt actually claims that insofar as remodeled police tactics have contributed to crime reduction in New York 
According to Wilson, police in Legalistic departments take a more restricted view of their job that is consistent with the law enforcement orientation of the department. Notably, Wilson does not associate police in Legalistic departments with extra-legal violence or with efforts to punish those who challenge an officer's authority. ${ }^{149}$ At the same time, while a focus on law enforcement may cause patrolmen to be less merciful than they otherwise might be, ${ }^{150}$ it also encourages them to leave alone those who are not breaking the law. Wilson quotes a sergeant in a Legalistic city:

It's Chief X's philosophy that the case is either unfounded or you had better have charged them with the offense which they are suspected of having committed. When we come across a group of kids scuffling after a basketball game, there's no such thing as 'messing around' in his eyes. Either there's no trouble and no reason to stop them or else you had better bring them in. ${ }^{151}$

Notice how the binary the sergeant describes excludes options an officer in a Watchman or order maintenance department might take. Either a crime is being committed and an arrest must be made, or no violation has occurred and the young people must be left to themselves. In neither case is it acceptable for a patrolman to intervene in an informal manner only-for instance, by ordering the teenagers to disperse or whacking one in the stomach. Moreover, it is tacitly assumed inappropriate to make an arrest for an "unfounded" case. It is true that the Legalistic result is presumably harsher where the law is infringed: a weekend in jail can be worse than a smack with a baton, and a violator would certainly prefer the Watchman cop who ignores the offense to the zealous Legalistic officer. At the same time, where the law is not being broken, there is neither official violence nor a dubious arrest. In other words, we experience an outcome more consistent with civil liberties.

City that it is increased surveillance, not the broken windows theory that explains things. Id. at 10-11.

149 See supra notes $128-35$ and accompanying text.

150 Recall that Legalism is associated with proactive policing and increased arrest rates. See supra note 52 and accompanying text. I address the tension between the aggressiveness of Legalistic departments and the improved climate for civil liberties I attribute to increased legalism in a section at the end of the Article.

151 WiLSON, supra note 1 , at 177. 


\section{B. Some Surprising Fruit of Legalism}

Speaking of the administrators in Legalistic departments, Wilson writes, "To some degree they demand that their officers enforce the laws because they believe it is right that all laws be enforced." "152 Wilson supports this statement with the example of the chief who admonished local businessmen about selling cigarettes to teenagers and the story of the Oakland Police Department's letter to parents that promised to cite their children if they failed to comply with a bicycle registration law. ${ }^{153}$ Wilson also mentions other reasons for enforcement: he points to administrators' desires to avoid corruption, a wish to remove the police from the political realm, and a hope that rigorously enforcing the law will achieve larger social objectives. ${ }^{154}$

Further supporting his contention that the administration in a Legalistic department believes in the enforcement of all laws, Wilson flatly declares, "[T]he police in a legalistic city obey the law themselves." 155 This is how Wilson introduces his example of the officers in a Legalistic city who would not jaywalk from headquarters to the parking lot. ${ }^{156}$ Admittedly, this is a small point in Wilson's analysis - a regrettable reality when one considers what an intriguing proposition it is. Wilson provides no other clear-cut instances of the phenomenon, although other rough examples can be found in different contexts.

One such rough example is the fact that "drug-store pornography" is safe in Legalistic cities. ${ }^{157}$ This may bespeak officers' leeriness about breaking the law. One imagines an officer who remembers, not only that interfering with the lawful vending of pornographic books is outside her purview, but also that she would be breaking the law herself if she were to seize them. The point generalizes to other instances in which an officer in a Legalistic department refrains

\footnotetext{
152 Id. at 180 .

153 Id. The step-up in enforcement of the registration ordinance was a response to the difficulty of solving bicycle thefts. $I d$.

${ }^{154} I d$. at 180-81. Mention of larger social objectives tends to call into question the legalism of the Legalistic departments, suggesting as it does an instrumental attitude towards the law. I contend that even where it is hoped that larger social objectives will be fulfilled by rigid enforcement of the law, a department may still be legalistic as opposed to instrumental in its attitude towards the law. This issue is discussed at length in the next section.

155 Id. at 180.

156 See supra notes 56-59 and accompanying text.

157 See supra note 54 and accompanying text.
} 
from an extralegal use of his or her power. Recall the statement of the sergeant about encountering youths scuffling after a basketball game. ${ }^{158}$ An arrest was ruled out in those situations where the charge would be unfounded. Again, this could simply be because the scene presents no law enforcement matter or because any arrest would itself be unlawful.

I want to emphasize two conceptual points at this juncture. The first, already discussed at the Article's outset, is that law and order are separate police missions. Once the meaning of each is separated from the "law and order" idiom, one can see that police achievement of one is severable from the other. A department like the NYPD may make society more orderly at the expense of law. Police action that advances order while violating the law renders society ceteris paribus, less lawful. The second point is that the Fourth Amendment, the Fourteenth Amendment, and the rest of the Constitution are just as much law as the penal code is law. The corollary is that every warrantless search of a home is just as much a deviation from the law as every act of shoplifting. ${ }^{159}$ To further accentuate the point, though New York City may be a much safer, more orderly city than it was twenty years ago, it may also be a less lawful city if the exploding numbers of stops and frisks include a substantial portion of actions based on racial profiling or conducted without reasonable suspicion. ${ }^{160}$ Viewed in the above light, it appears self-evident that a police department that treats the law more as an end and less as a means will seek to reduce its own contribution to illegality by limiting civil liberties violations by its officers.

Conceptual intuitions aside, the reader is right to be skeptical of the claim that a legalistic attitude in a department entails that officers will be more circumspect regarding citizens' rights. In particular, one can accept Wilson's evidence that officers in his Legalistic departments were loath to jaywalk or commit other crimes accessible to private citizens without thereby accepting that this antipathy to breaking the law extended to constitutional matters encountered in the course of pursuing

\footnotetext{
158 See supra note 145 and accompanying text.

159 Insofar as constitutions are special, foundational law, the former may be even more significant from the perspective of legality.

${ }^{160}$ Compare Harcourt's comments on Wilson and Kelling: "On close inspection, the desired order depends on a lot of disorder, irregularity, and brutality." HARCOURT, supra note 85, at 127. "But in fact, irregularity is central to their [Wilson and Kelling's] analysis, because it is precisely the application of universal rules that most clearly undermines the order-maintenance function.” Id. at 128. "In effect, regularity on the street depends on irregularity in police practice-mixed, of course, with some regularity in the choice of suspects.” Id. at 129.
} 
crime. On this point, my argument calls for more evidence than Wilson's book (and my critical reinterpretation of it) can yield.

The assumption that illegality in the course of policing is somehow different is also the target of an article by Bennett Capers. Capers writes about how police lose legitimacy in the eyes of the community when officer infractions go unrecognized and unpunished. ${ }^{161}$ He criticizes the double standard perceived by members of minority communities. Community members see that "they [the police] are our designated enforcers of the law, but too often function outside of the law themselves." 162 Such behavior erodes the willingness of people in these communities to support the police and obey the law themselves. ${ }^{163}$ Focusing on perjury by officers, Capers argues for far more investigations and prosecutions of officers who lie under oath. ${ }^{164}$ This remedy is superior to internal, administrative discipline or fines because it treats the perjuring officer the same as the perjuring civilian. ${ }^{165}$ In this way, it strikes a blow against the double standard at a point where the standard is weak: it punishes violations of a clear-cut, uncontrovertially bad crime as opposed to violations of a vague and politically contested constitutional standard. ${ }^{166}$

I agree with Capers, especially with his elucidation of the problem of a double standard. Capers' choice of perjury as the place to initiate reform is particularly interesting. Previously, I worried that Wilson's flat claim- “the police in a legalistic city obey the law themselves"-might not embrace law violations connected to the work of law enforcement itself, e.g., excessive use of force or bogus searches. Perjury is a curious case as such because it is both a crime that civilians can commit and a crime committed in relation to a police officer's onduty tasks. Moreover, as Capers notes, it is a relatively unambiguous offense. If Wilson is correct that police in his Legalistic departments obey the law themselves, then his theory would predict reduced rates of perjury by officers testifying about their work. On the other hand, if this were found not to be the case, it would cast doubt on Wilson's claim that

${ }^{161}$ Bennett Capers, Crime Legitimacy and Testilying, 83 IND. L.J. 835 (2008).

162 Id. at 837.

163 Id. at 865.

164 Id. at 873.

165 Id. at 872.

${ }^{166}$ See id. at 867 ("[I]t may be difficult to build consensus around curbing excessive force, profiling, or under-enforcement on the streets. Testilying, by contrast, tends to be more uniformly condemned.”). 
a law enforcement orientation imposed by the brass engenders general habits of compliance with the law in a department's lower ranks. The claim would then have to be qualified so as to distinguish cases like jaywalking from those that bear on the law enforcement mission. Officer perjury thus presents an interesting test case for this section's claim that increased legalism in a department makes officers more averse to breaking the law categorically, including in the course of their police work.

\section{A Note on Value and Criterion in Policing}

Instrumentalism and legalism each describe the attitude of a police organization towards the law. Instrumentalism indicates that a department regards law as a means-law is of importance only to the extent that it serves or constrains pursuit of a collateral policy goalwhile legalism signifies that law is viewed as an end in itself. Since instrumentalism and legalism both address orientation to law, they are not exhaustive of an organization's values. Specifically, an organization may possess a legalistic or instrumental approach to the law while harboring other background values, values constitutive of an ultimate good that police believe their work serves. In like manner, legalism and instrumentalism are distinct from an organization's criteria of success. Arrest rate, for instance, may be used to assess officers in both legalistic and instrumental departments. In this section, I will elaborate on the distinction between a department's attitude to the law, its ultimate values, and its criteria of success.

In a police department, a number of success criteria are possible: arrest rates, crime rates, conviction rates, polls of citizen opinion, the price of street drugs, and number of complaints are all possibilities. Moreover, any of these could be used in either a legalistic or an instrumental department. In an instrumental department, high arrest rates could indicate success on the theory that more arrests means more disorderly persons tagged and corralled. For a legalistic department, the same metric could indicate success because more arrests means more criminals are being apprehended and placed on the path to prosecution and conviction.

Appreciating that the same criterion may be adopted for two different purposes allows us to understand how, in a modern order maintenance department, an insistence on producing high numbers of misdemeanor arrests and citations is consistent with instrumentalism. Recall that according to Harcourt, the number of misdemeanor arrests 
increased in New York with the turn towards broken windows policing. ${ }^{167}$ The campaign against freelance windshield washing was also built on the tactic of ticketing squeegeemen and then arresting them when they failed to respond to the citation. ${ }^{168}$ Of course, the point of these arrests was not to enforce the law but to increase the level of order in the city. Since the recipe for increased order called for more arrests, measuring success based on number of arrests is perfectly consistent with an instrumental approach to the law. This is a truth obscured in Varieties of Police Behavior: In the book, only departments with the Legalistic style made a point of judging their success on the basis of arrest and ticket figures. ${ }^{169}$

Just as an instrumental department and a legalistic department may share a criterion, they may also share the same ultimate values. Justice, safety, and quality of life are examples of ultimate values a department or an individual officer might harbor. ${ }^{170}$ In an order maintenance department, officers tasked with stepping up interdictions of turnstile jumpers (an order maintenance task) might sincerely describe their work in terms of "making the city a better place to live." Although order maintenance defines the immediate task, the background value that allows officers to make sense of their work is promoting quality of life. In a legalistic organization, an officer arresting a juvenile for shoplifting might also describe what she is doing as "making the city a better place to live." Here, the same background value is present and informs the officer's work even if enforcing the law is treated, in practice, as a task of self-evident significance. ${ }^{171}$

\footnotetext{
167 See supra note 84 and accompanying text.

168 See Kelling \& COLES, supra note 80, at 142-43.

169 E.g., WiLSON, supra note 1, at 180.

170 Cf. Steve Herbert, Morality in Law Enforcement: Chasing "Bad Guys" With the Los Angeles Police Department, 30 LAW \& SOC’y REV. 799, 799 (1996) (“[T]he enforcement of law is often understood by police officers as a moral as well as a legalistic enterprise.”). Herbert offers the example of an officer responding to a domestic violence call. $I d$. at 803-04. When the officer informs the victim that the law requires her husband be arrested, she protests. Id. at 804 . The officer explains to the woman that the law gives him no choice, but he also tells her that what her husband has done "simply isn't right" and that she will be able to sleep in peace if he is locked up. Id.

${ }^{171}$ Readers with an eye for conceptual inconsistencies may insist that my past description of legalism, "regarding the law as an end in itself," is inconsistent with what I now say about officers in legalistic departments holding to other ultimate values. After all, if something is truly an end in itself, then it cannot be valued for some underlying, collateral reason. There are two answers to this objection. The first is that legalism is a
} 
The foregoing distinction between legalism and background values draws support from (and is needed to make sense of) certain passages in Varieties of Police Behavior. Wilson informs us that the police in Legalistic cities "do not arrest because they like making arrests . . . or love the penal code." ${ }^{172}$ He goes on to say:

The [Legalistic] chief also knows that the law is a device to achieve certain social objectives-order, peace, security, certainty, and liberty. He is aware that by enforcing certain laws he can achieve the purposes of other laws, and this gives him and his department a reason to enforce laws that otherwise might appear trivial and thus be ignored. Enforcing traffic laws is desirable not simply because it is their duty but because such enforcement is one way to prevent automobile accidents.... Furthermore, stopping cars for traffic infractions affords an opportunity to check the identity of the driver and the registration of the car; from time to time, the police discover fugitives, stolen merchandise, illegal weapons, and stolen cars this way. This, in turn, leads to even more arrests.

The same instrumental view of the law extends into other areas where the police act on their own initiative. A drunk becomes the victim of a strong-arm robber; arrest him and you prevent a robbery. Juvenile vandalism can, the police believe, lead to a career in crime; better to investigate now, and take it seriously now. Teenagers loitering on a street corner at night might cause mischief later on .... Besides being illegal, vice also leads to

trait of a department; I have stated elsewhere that the beliefs expressed by individual officers about their work are largely invariable across police styles-that they are a function of occupational culture, not organizational culture. The second reply is that the idea of "an end in itself” is being used loosely. While certain underlying values may give the law enforcement mission significance for the legalistic department and its officers, in practice, the law is treated as if it were an end in itself. In other words, law enforcement is approached like a prima facie good, even if in reality that approach is ultimately conditioned upon acceptance of background values.

Another answer is that the background values function to rationalize or justify (when rationalization and justification are necessary) work that is otherwise cold, distressing, or bureaucratic. It is the occasions when a chief or line officer finds herself questioning the significance of arresting every juvenile shoplifter that the background value-making the community safer or its people happier-gets invoked to rationalize or impart meaning to the law enforcement practice.

172 WILSON, supra note 1, at 179. 
muggings and the rolling of drunks; arrest prostitutes and you reduce the number of rollings. ${ }^{173}$

At first glance, the quoted matter is at variance with the separation of legalism and instrumentalism. Wilson even uses the words "instrumental view of the law" in relation to a Legalistic department. From these paragraphs, it would seem that all departments are actually instrumental departments. However, a more deliberate reading shows that this is not the case.

What Wilson wants to make clear is that police in Legalistic departments (both chiefs and patrol officers) are not law-enforcement automatons. He is not, however, abandoning the idea that Legalistic departments are distinguished by a focus on law enforcement. Notice how Wilson phrases his descriptions, "Besides being illegal, vice also leads to muggings." Per Wilson, it is still important to the officer in a Legalistic city that vice is illegal, but officers are not blind to, and indeed value, the collateral benefits thought to stem from arresting prostitutes. In fact, these supposed wages of law enforcement might even be, at bottom, what grounds commitment to enforcing the law. And yet, they are still only background values, goods that the police hope or anticipate they are achieving by law enforcement. Even where order is the background value, there is still a difference between an order maintenance department, where law is only of importance insofar as it is believed to be a useful instrument of public order, and the legalistic department in which officers hope that public order will result if the laws are enforced. In the former, the laws will only be enforced as long as they are thought to be an effective tool; whereas in the latter, the laws will be enforced regardless, even if the police only have the faintest expectation that order will be achieved thereby.

\section{Legalism and Aggressive Policing}

The reader who notes the association of Wilson's Legalistic style with proactive policing may for that reason doubt whether increased legalism could be a boon to civil liberties. As I previously described, the police in Legalistic cities were disinclined to turn a blind eye or practice live and let live when presented with a violation of the law. ${ }^{174}$ Statistically, the Legalistic style entailed increased arrest rates,

\footnotetext{
${ }^{173} I d$. at 182.

${ }^{174}$ See supra notes $49-53$ and accompanying text.
} 
especially for crimes of vice like prostitution. ${ }^{175}$ The police also insisted on the prosecution of shoplifters and writers of bad checks, even when the cheated merchant would rather not press charges. ${ }^{176}$ When it came to shoplifters, the police were said to "frown on stores that seek only restitution rather than prosecution." ${ }^{177}$ In one Legalistic city, not even the child owners of unlicensed bicycles were exempt from police intrusion on behalf of the law. ${ }^{178}$ Most strikingly, Wilson describes how the aggressive law enforcement campaign in Oakland was experienced as harassment by the denizens of minority communities newly inundated with officers bent on identifying criminals and making arrests. ${ }^{179}$ This image, of police officer as equal parts busybody and rigid minder of rules, hardly betokens increased civil liberty.

My first response to this objection is to clarify: I have not argued that a purely legalistic department is the key to a policing regime of perfect civil liberty but rather have made the narrower claim that cities with order maintenance departments could improve their civil liberties record by injecting their departments with a measure of legalism. In other words, my contention is that order maintenance departments fall too close to the instrumentalist end of the spectrum at present and could benefit from a move in the other direction. In this Article, I have given two reasons to think that pushing the needle back will be remedial: it will limit what is considered a police matter and increase officer compliance with the law. The former is a matter of assuaging excess in the order maintenance department and the latter is a request to tap a peculiar benefit that legalism offers. Wherever the ideal point for civil liberties along the legalistic-instrumental lies, this Article gives reasons to think that order maintenance departments are currently still somewhere on the instrumental side of it.

My second response is also largely clarificatory: Wilson's Legalistic style is not the same thing as legalism in terms of the legalistic-instrumental spectrum. Wilson identified the Legalistic style

\footnotetext{
175 WiLson, supra note 1, at 173-74.

${ }^{176} I d$. The association between aggressive policing and the Legalistic style was not lost on later authors. Slovak, who treated aggressiveness as one measurement of Legalism, writes, "Agencies in which officers on their own initiative make many arrests, give traffic citations, and intervene in local disputes are those Wilson would term legalistic.” SLOVAK, supra note 9, at 112-13.

177 WiLsON, supra note 1 , at 176.

178 Id. at 180.

${ }^{179} I d$. at 190 (speaking of the gratingly "high volume of police citizen interactions”).
} 
to describe a collection of traits that he observed cluster together. As such, the style embraced several characteristics, only one of which was a focus on law enforcement. ${ }^{180}$ Apart from being aggressive, Legalistic departments were also formalized and professionalized, placing a premium on the use of technology and written reports. ${ }^{181}$ As I previously mentioned, the Legalistic departments of the 1960s that Wilson observed were already part of a movement in American policing, the professionalism movement, that would become the norm by the 1980s. ${ }^{182}$ The turn to order maintenance in cities like New York came only after the professionalism movement had done its work at remolding American policing. This is the story of how the beat cop (the old Watchman departments) gave way to officers in cars (the professionalism movement), only to return to walking the streets at the behest of advocates of broken windows policing.

Given this history, we should expect that a modern order maintenance department like the NYPD, having been shaped by the professionalism movement, ${ }^{183}$ would still match the Legalistic departments of the 1960s in respects other than orientation to law enforcement. As I previously explained, the modern order maintenance department is not to be confused with a passive, creaky Watchman department. ${ }^{184}$ To the contrary, apart from where the NYPD falls on the instrumental-legalistic spectrum, I assume that it still looks like the Legalistic departments of the past insofar as personnel practices, record keeping, and aggressiveness are concerned. Synergy between order maintenance and professionalized policing is illustrated by the testimony of dissident officers in Floyd v. City of New York: ${ }^{185}$ these officers testified to quotas imposed by stationhouse supervisors for arrests, citations, and stop-and-frisk. ${ }^{186}$ The use of such data by higher-ups to increase the scale of policing and the production of arrests was a method

\footnotetext{
180 See supra note 44 and accompanying text.

181 See supra note 45-49 and accompanying text.

182 See supra notes 60-63 and accompanying text.

183 The story told by Kelling and Coles' book is largely one of police departments, including the NYPD, that had been transformed by the professionalism movement rediscovering the traditional order maintenance role of the police. See KELLing \& COLES, supra note 79, at 77-89, 102-03, 108-09.

184 See supra note 94 and accompanying text.

185959 F. Supp. 2d 540 (S.D.N.Y. 2013).

186 Joseph Goldstein, Stop-and-Frisk Trial Turns to Claim of Arrest Quotas, N.Y. Times, Mar. 21, 2013, at A23.
} 
of Legalistic chiefs described by Wilson. ${ }^{187}$ Thus data collection, a legacy of the professionalism movement, continues to be used in New York in the pursuit of order maintenance ends. Although one might call for a return to the old laxity of the Watchmen departments, this issue is collateral to the question of whether a modern urban department should have a more instrumental or legalistic attitude towards the law.

My final response addresses the fear that increased legalism will only escalate enforcement of petty misdemeanors, a concern reinforced by the breadth of contemporary penal codes. ${ }^{188}$ To assuage such fears, I argue that increased legalism means that police will judge the importance of violations of the law on the basis of what the law has to say about particular unlawful conduct rather than a collateral standard like that of broken windows theory. This is an adaption of a point made by Wilson in relation to Watchman departments, of which he writes, "The police are watchman-like not simply in emphasizing order over law enforcement but also in judging the seriousness of infractions less by what the law says about them than by their immediate and personal consequences." 189

If we may assume that legalism, by contrast, entails that police will judge the seriousness of infractions by what the law says about them, then we may expect increased legalism to reduce officers' efforts to enforce misdemeanor laws that are prioritized by broken windows thinking. For example, while the law defines graffiti, public intoxication, possession of small quantities of marijuana, and turnstile jumping as minor offenses, these possess outsized significance in broken windows theories. While we know from Varieties of Police Behavior that switching from a Watchman style to a Legalistic one entailed increased arrests for petty offenses, this may simply reflect a shift to the use of arrest rather than informal sanctions in response to the same crimes. It does not follow that Legalistic officers will spend more time responding to and investigating these offenses. On the contrary, we may fairly expect that where law enforcement is a department's focus that their priorities will, to a greater extent than in order maintenance departments, match the hierarchy described in the penal code. As a result, the use of misdemeanor arrest might decline rather than augment with increased legalism.

187 See supra note 48 and accompanying text.

188 See William J. Stuntz, The Collapse of American Criminal Justice 260 (2011) (discussing contemporary legislatures’ penchant for defining new crimes).

189 WiLSON, supra note 1, at 141. 
Given the above objections, the reader may wonder how I imagine the streetlevel behavior of officers in a department that has received the recommended "shot of legalism." Generally, my vision of a city with a legalistic police department is one in which the institutional culture reflects a belief that infringements of the Constitution are just as much lamentable departures from the rule of law as penal code violations. In such a city, an officer tempted to stop and frisk a pedestrian who looked "suspicious" to the officer, perhaps because of the color of the pedestrian's skin or the neighborhood in which he is walking, would stop and consider that he would be violating the law himself if he cannot identify specific, articulable facts evidencing criminality. ${ }^{190}$ Even though the officer may believe that he could make the city safer by stopping everyone about whom he has a hunch, he sees an unconstitutional stop as a serious evil to be avoided and refrains from interfering with the pedestrian.

I also imagine a department in which recognition that the authority of the police stops at the limits of the law is ingrained in the institutional culture. Imagine that an officer sees a group of teenagers standing on a street corner. They are loud and occasionally jeer passersby. Pedestrians are sufficiently scared or bothered that they walk to the other sidewalk when approaching the intersection. Before the officer uses her authority to interfere with the teenagers, formally or informally, she firsts asks herself if any laws are being broken. If the teens are not violating the law, she leaves them be, however disruptive of urban order their behavior may be.

Furthermore, I conceive of a department in which enforcing the law by responding to imminent threats of crime and catching felony offenders is prioritized. This may mean that the police in a more legalistic department become reactive rather than proactive, that they focus on solving felonies after they are reported by citizens. In such a department, the work of detectives would be valorized, whereas the literature on order maintenance shows little interest in this police role.

Of course, any benefits for civil liberties from increased legalism are limited by the law itself. If the law of investigative detention gives the police too much leeway to follow their hunches and prejudices or if legislatures criminalize too much conduct, strict adherence to the law safeguards only the rule of law, not substantive liberty and equality. Unless we assume that civil liberty is synonymous with legality, we

190 See Terry v. Ohio, 392 U.S. 1, 21 (1968). 
must accept that aggressive policing of bad law can impair civil liberty.

Nonetheless, I have argued that a move away from instrumentalism towards legalism will improve civil liberties in cities with order maintenance departments. Legalism, on the spectrum I have defined, does not entail that the police are aggressive or proactive like those in Wilson's Legalistic departments. Moreover, increased legalism does not entail that departments will have the resources to enforce all criminal laws, all the time. Tradeoffs will be necessary. But whereas in order maintenance departments, those tradeoffs favor order maintenance-for instance, officers are required to meet stop and frisk quotas - in legalistic departments, those tradeoffs will favor enforcement of laws against serious crimes-for instance, more detectives are hired to investigate rapes and homicides.

\section{CONCLUSION}

This Article makes a conjecture about the relationship between where a police organization falls on the spectrum between instrumentalism and legalism and infringement of civil liberties by its officers. The Article leans on Wilson's work: his insightful descriptions, his anecdotes, and his theories. At the same time, the Article draws lessons from Wilson's work that diverges from those he drew himself.

Broken Windows was a far more prescriptive piece than Varieties of Police Behavior. Knowing as he did the difference between a Watchmen department and a Legalistic department, Wilson was able to spot what he thought was the problem with American policing in the 1980s: too much emphasis on crime control conducted from Crown Victorias, and not enough focus on the traditional work of the police of enforcing public order while walking beats. Because he understood so well the difference between Watchmanism and Legalism, Wilson knew that he was recommending police step outside the law to do their work. Using Wilson's material, this Article takes the normative road that Wilson did not. Whereas Wilson called for order maintenance policing to restore the safety and livability of American cities, I emphasize the cost that order maintenance takes on civil liberties and how a move back towards legalism could abate that cost.

This Article has hopefully shown that civil liberties violations are a product of order maintenance philosophies and that such violations, while not objectionable given an instrumental view of the law, are objectionable on a legalistic view. I argued first (in Section III.A) that violations are symptomatic of order maintenance because of 
Vol. 19:2

the expanded conception of the police role that order maintenance carries with it. I next contended (in Section III.B) that police in a legalistic department are more likely to obey the law, including its civil liberties provisions, themselves. For both reasons, I believe that a shift towards legalism can decrease police infringement of civil liberties in order maintenance police departments. 